https://journal.uwgm.ac.id/index.php/abdimasmahakam

E-ISSN: 2549-5755

Januari 2020, Vol. 4 No. 01

Received: Agustus 2019

Accepted: November2019

Published: Januari 2020

Article DOI: http://dx.doi.org/ 10.24903/jam.v4i1.812

\title{
Workshop dan Simulasi Tes TOEFL pada Peserta Pelatihan Kepemimpinan Tingkat IV Lembaga Administrasi Negara
}

\author{
Dedi Rahman Nur \\ Universitas Widya Gama Mahakam Samarinda \\ d.blues84@gmail.com \\ Yosieka Maharani \\ Universitas Widya Gama Mahakam Samarinda \\ Yosieka94@gmail.com
}

\begin{abstract}
Abstrak
Tes TOEFL merupakan tes kemampuan Bahasa Inggris yang masih diperhitungkan dalam dunia kerja pada saat ini. Oleh karena itu, hampir semua instansi pemerintah mewajibkan kepada pegawai maupun calon pegawai untuk memiliki score TOEFL. Maka dari itu, kami dari tim pengabdian mencoba mengambil kesempatan tersebut untuk bisa mengadakan pelatihan atau sejenis workshop kepada seluruh peserta Pelatihan Kepemimpinan di Lembaga Administrasi Negara dengan jumlah peserta 60 orang. Di lembaga tersebut Tes TOEFL dijadikan sebagai salah satu persyaratan untuk lulus dalam pelatihan, maka dari itu pelatihan ini dibutuhkan untuk membekali seluruh peserta sebelum mereka mengikuti tes yang sebenarnya. Pengabdian ini dilaksanakan di aula serbaguna Lembaga Administrasi Negara (LAN). Masalah yang dihadapi oleh peserta adalah peserta merupakan aparatur negara yg sudah tidak lama bergelut dengan dunia akademis sehingga sulit untuk memahami konteks bacaan terlebih dalam bahasa Inggris. Maka dari itu, pemateri berusaha memberikan tips dan trik mengerjakan tes TOEFL seefisien mungkin.
\end{abstract}

Kata Kunci: tes; TOEFL; Lembaga Administrasi Negara; simulasi.

\section{Pendahuluan}

TOEFL merupakan test proficiency, yaitu tes yang digunakan untuk mengukur kemampuan bahasa Inggris seseorang tanpa dikatkan secara langsung dengan proses belajar mengajar (Purnaning, Estiwi Retno dkk:2012). Ada tiga jenis tes TOEFL yaitu: (1) PBT (Paper-Based TOEFL), (2) CBT (Computer-Based TOEFL), dan (3) iBT (Internet-Basd TOEFL), (Hudha, Nurul. 2014).

Dalam dunia kerja dan dunia pendidikan sekarang ini, penggunaan Bahasa Inggris sangat penting. Sebagian literature yang harus dikuasai pengajar dan peserta didik banyak menggunakan bahasa Inggris sehingga mau atau tidak mereka dituntut untuk menguasai Bahasa Inggris. Indikator pencapaian penguasaan Bahasa Inggris sesorang dapat diukur 
https://journal.uwgm.ac.id/index.php/abdimasmahakam

E-ISSN: 2549-5755

Januari 2020, Vol. 4 No. 01

dengan beberapa tes kemampuan berbahasa Inggris dintaranya dengan TOEFL (Arbain, Taufik, Ngoc, \& Nur, 2017; Arbain, Taufik, \& Nur, 2017).

TOEFL digunakan sebagai syarat penerimaan mahasiswa baru di beberapa universitas, sebagai syarat untuk pelamar kerja, dan sebagai syarat untuk karyawan swasta atau pegawai negeri sipil yang ingin mengajukan kenaikan pangkat (Irawati, Lisrohli:2016). Berdasarkan hal tersebut, maka tim pengabdian masyarakat dipandang perlu untuk menyelenggarakan workshop dan simulasi tes TOEFL untuk membekali aparatur sipil negara (ASN) dalam peningkatan Jabatannya.

\section{Metode}

Pengabdian ini dilakukan selama 2 hari yaitu pada hari Sabtu, 14 Desember 2019 - Minggu, 15 Desember 2019 di Aula Gedung Lembaga Administrasi Negara. Pada tahap pertama merupakan perkenalan TOEFL dan setelah itu dilanjutkan dengan Simulasi Tes TOEFL. Materi pembelajaran yang diberikan fokus pada Listening skill, Structure and Written Expression, dan Reading Comprehension. Pada hari pertama hingga difokuskan pada building knowledge, dan hari kedua diperuntukkan untuk tes simulasi.

\section{Hasil dan Pembahasan}

Dari simulasi tes TOEFL yang dilaksanakan, maka diperoleh hasil sebagai berikut:

\begin{tabular}{llcccc}
\hline NO & \multicolumn{1}{c}{ NAMA } & SECTION 1 & SECTION 2 & SECTION 3 & TOTAL \\
\hline 1 & ASMADIANA & 39 & 35 & 38 & 373 \\
2 & PENINA & 45 & 45 & 54 & 480 \\
3 & BUDI RELA PRIHARTONO & 41 & 41 & 43 & 417 \\
4 & SANTI SARDI & 39 & 26 & 43 & 360 \\
5 & WHISNU ADY PRIYONO & 49 & 46 & 54 & 497 \\
6 & SRI WINARYANTI & 32 & 43 & 47 & 407 \\
7 & CHEIRIYAH IDHA & 39 & 32 & 31 & 340 \\
8 & YUNUS & 45 & 44 & 54 & 477 \\
9 & SURYADI AMIN & 37 & 41 & 42 & 400 \\
10 & JAINUDDIN & 41 & 40 & 40 & 403 \\
11 & ETI SULARSARI & 32 & 33 & 35 & 333 \\
12 & TAUFIK HIDAYAT & 37 & 36 & 53 & 420
\end{tabular}


https://journal.uwgm.ac.id/index.php/abdimasmahakam

E-ISSN: 2549-5755

Januari 2020, Vol. 4 No. 01

\begin{tabular}{|c|c|c|c|c|c|}
\hline $\mathrm{NO}$ & NAMA & SECTION 1 & SECTION 2 & SECTION 3 & $\begin{array}{l}\text { TOTAL } \\
\text { SCORE }\end{array}$ \\
\hline 13 & ARIFUDDIN & 37 & 27 & 34 & 327 \\
\hline 14 & ODIE HERMAWAN & 45 & 44 & 39 & 427 \\
\hline 15 & EVA MARTINI HIDAYAT & 35 & 19 & 42 & 320 \\
\hline 16 & ADE AMANDA & 45 & 40 & 39 & 413 \\
\hline 17 & AININ FIDIYAH & 43 & 43 & 37 & 410 \\
\hline 18 & ARRIZAL RAHMAN & 35 & 33 & 34 & 340 \\
\hline 19 & ASLAMIAH & 38 & 45 & 40 & 410 \\
\hline 20 & ELIESER YOHANES & 31 & 37 & 28 & 320 \\
\hline 21 & DODDY MA'RUF & 31 & 37 & 34 & 340 \\
\hline 22 & DWI RAHMAWATI & 35 & 37 & 34 & 353 \\
\hline 23 & DWI JUNIARTI & 32 & 33 & 38 & 343 \\
\hline 24 & DODI HARTANTO & 32 & 36 & 37 & 350 \\
\hline 25 & TAUFIQ RACHMAN & 32 & 31 & 32 & 317 \\
\hline 26 & MARGARETTYANINGSIH & 33 & 38 & 32 & 343 \\
\hline 27 & MIFTAKHUL JANNAH & 35 & 35 & 32 & 340 \\
\hline 28 & LULUK & 35 & 31 & 32 & 327 \\
\hline 29 & JASMAN HADI & 37 & 31 & 32 & 333 \\
\hline 30 & RONALD & 32 & 37 & 34 & 343 \\
\hline 31 & FIBTIN & 41 & 33 & 39 & 377 \\
\hline 32 & GUNTUR & 37 & 33 & 35 & 350 \\
\hline 33 & HENDRICK CHAIRI & 44 & 37 & 40 & 403 \\
\hline 34 & IKHSAN KURNIAWAN & 33 & 33 & 34 & 333 \\
\hline 35 & HERYANTO & 44 & 40 & 39 & 410 \\
\hline 36 & ISTIANA & 44 & 28 & 31 & 343 \\
\hline 37 & IRENA FEBRIANI & 33 & 36 & 32 & 337 \\
\hline
\end{tabular}


https://journal.uwgm.ac.id/index.php/abdimasmahakam

E-ISSN: 2549-5755

Januari 2020, Vol. 4 No. 01

\begin{tabular}{llcccc}
\hline NO & NAMA & SECTION 1 & SECTION 2 & SECTION 3 & TOTAL \\
& & & & & \\
\hline 38 & HENDRYR \\
39 & HAPISIN & 39 & 41 & 40 & 400 \\
40 & NURLINDA & 38 & 50 & 38 & 420 \\
& & 32 & 32 & 32 & 320 \\
\hline
\end{tabular}

Berdasarkan total score di atas, ada 29 peserta yang lulus dengan total score di atas 400 dan yang lainnya masih di bawah 400. Satu peserta mencapai score tertinggi yaitu 497 dan score terendah adalah 320. Score rata-rata dari keseluruhan peserta adalah 378.

\section{Simpulan dan rekomendasi}

Berdasarkan hasil tes di atas dapat kita simpulkan bahwa sebagian dari jumlah peserta tidak dapat mencapai score minimal kelulusan. Hal tersebut dikarenakan keterbatasan peserta akan kosakata Bahasa Inggris dan terbatasnya waktu yang dimiliki untuk mengerjakan seluruh soal tes TOEFL sehingga peserta merasa kewalahan. Namun sebagian juga dari peserta dapat mencapai score tuntas bahkan mencapai score yang sangat tinggi. 


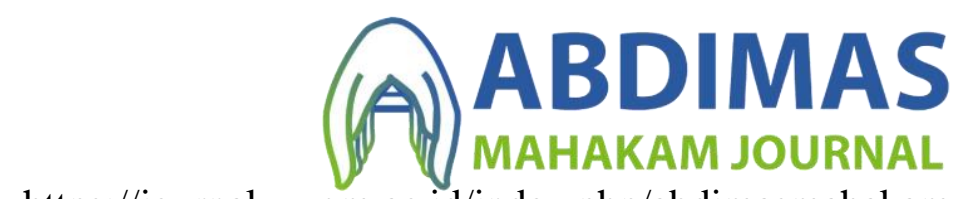

https://journal.uwgm.ac.id/index.php/abdimasmahakam

E-ISSN: 2549-5755

Januari 2020, Vol. 4 No. 01

\section{Daftar Pustaka}

Arbain, A., Taufik, A., Ngoc, T. T. N., \& Nur, D. R. (2017). Basic English Drill. Yogyakarta: Andi Publisher.

Arbain, A., Taufik, A., \& Nur, D. R. (2017). Daily English Phrases Book. Samarinda: UWGM Press.

Fitriana, R., Nur, D. R., \& Arbain, A. (2017). Pelatihan dan Simulasi IELTS bagi Mahasiswa dan Dosen di Lingkungan Fakultas Pendidikan dan Keguruan Program Studi Bahasa Inggris Universitas Widya Gama Mahakam Samarinda. Jurnal Abdimas Mahakam, 1(2), 88-95.

Hudha, Nurul dkk. 2014. Upgrade TOEFL Score. CMedia Imprint Kawan Pustaka: Jakarta Selatan.

Irawati, Lisrohli., Widiyantari, Yunita. 2016.The Master of TOEFL. Bentang Pustaka: Yogyakarta

Mousavi, S. A., Arizavi, S., \& Namdari, N. (2014). The effect of test preparation on the test performance the case of the IELTS and TOEFL iBT reading tests. International Journal of English and Education, 3(2), 10-22.

Nguyen, T. N. H. (2007). Effects of test preparation on test performance the case of the IELTS and TOEFL iBT listening tests. Melbourne Papers in Language Testing, 12(1), 1-23.

Purnaning, Estwi Retno dkk. 2012. Tip dan Trik Melejitkan Score TOEFL. CMedia Imprint Kawan Pustaka: Jakarta Selatan. 